\title{
Determining Environmental Factors Affecting Bird Diversity
}

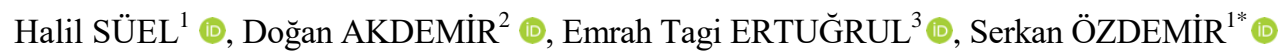 \\ ${ }^{1}$ Isparta University of Applied Sciences, Sütçüler Prof. Dr. Hasan Gürbüz Vocational School, \\ Isparta, TURKEY \\ ${ }^{2}$ Balıkesir Universitesi, Dursunbey Vocational School, Balıkesir, TURKEY \\ ${ }^{3}$ Çanakkale Onsekiz Mart University, Bayramiç Vocational School, Çanakkale, TURKEY \\ *Corresponding Author: serkanozdemir@isparta.edu.tr
}

Received Date: 09.06.2021

Accepted Date: 03.09.2021

\begin{abstract}
Aim of study: The main purpose of the study is to determine the site factors affecting bird diversity.

Area of study: This study was performed in the Çandır District, Isparta which is located inner part of the Western Mediterranean region.

Material and methods: In present study, Observations were conducted regularly in a total of 43 sample sites in Çandır District, throughout each month in 2016. Also, each sample site was observed using point-counting techniques from the direct observation techniques. In the present study, alpha diversity (Species richness, Menhinick, Margalef, Shannon-Wiener, Brillouin, Simpson, Berger-Parker, and Fisher's Alpha) values were calculated, and significant variables were determined by using correlation analysis.

Main results: A significant correlation $(\mathrm{p}=0.05)$ was determined between alpha diversity values and both environmental and climatic variables. Principal component analysis (PCA) was used to compare alpha diversity indexes with each other. Species richness, Shannon, and Brillouin indexes were determined as the variables having the strongest correlation with environmental variables.

Highlights: A better understanding of factors affecting bird species diversity, which are sensitive species of ecosystems, is of great importance for the detection and monitoring of future changes. Especially when it is considered in terms of parameter selection for modeling studies, the mentioned importance increases even more. Therefore, it is thought that the results of this research will be important both in terms of studies conducted in Çandır District and in terms of studies on bird diversity.

Keywords: Alpha Species Diversity, Bird Density, Correlation, Ecosystems, Principal Component Analysis
\end{abstract}

\section{Kuş Çeşitliliğini Etkileyen Çevresel Faktörlerin Belirlenmesi}

$\ddot{O} \mathbf{z}$

Çalışmanın amacı: $\mathrm{Bu}$ çalışmanın ana amacı kuş çeşitliliğini etkileyen çevresel faktörlerin belirlenmesidir.

Çalışma alanı: Çalışma Batı Akdeniz Bölgesinin iç kesimlerinde yer alan Isparta ilinin Çandır yöresinde gerçekleştirilmiştir.

Materyal ve yöntem: Çalışmada 2016 y1lında aylık olarak düzenli şekilde gerçekleştirilen arazi gözlemlerinden elde edilen 43 örnek alan verisi kullanılmıştır. Her bir örnek alanda noktada sayım tekniği ile gözlemler gerçekleştirilmiştir. Çalışmada alfa çeşitlilik indeksleri hesaplanarak korelasyon analizi ile bu indisler ile ilişkili olan çevresel değişkenler belirlenmiştir.

Temel sonuçlar: Alfa çeşitlilik indeksleri ile hem çevresel değişkenler hem de iklim değişkenleri arasında önemli ilişkiler $(\mathrm{p}=0.05)$ tespit edilmiştir. Temel Bileşenler Analizi kullanılarak alfa çeşitlilik indislerinin birbirleri ile olan ilişkileri ortaya koyulmuştur. Tür zenginliği, Shannon indeksi, ve Brillouin indeksi değişkenler ile en yüksek korelasyon gösteren değişkenler olarak tespit edilmiştir.

Araştırma vurguları: Ekosistemlerin hassas türlerinden olan kuşlara ait çeşitliliği etkileyen faktörlerin belirlenmesi, gelecekteki değişimlerin tespiti ve izlenmesi açısından büyük önem taşımaktadır. Özellikle modelleme çalışmaları için parametre seçimi bakımından düşünüldüğünde bu önem daha da artmaktadır. $\mathrm{Bu}$ nedenle, bu araştırmanın sonuçlarının hem Çandır İlçesi'nde yapılan çalışmalar açısından hem de kuş çeşitliliği üzerine yapılmış çalışmalar açısından önem arz edeceği düşünülmektedir.

Anahtar Kelimeler: Alfa Tür Çeşitliliği, Kuş Yoğunluğu, Korelasyon, Temel Bileşenler Analizi

Citation (Atıf): Suel, H., Akdemir, D., Ertugrul, E. T., \& Ozdemir, S. 


\section{Introduction}

Biological diversity values are the most important parameters that indicate the liveliness of ecosystems (Walker, 1995). Biological diversity indexes, which are indicators of biological diversity are an easy tool to monitor the continuity and permanency of ecosystems. A significant part of the global biological diversity is attributed to the diversity of birds (Tews et al., 2004; Sutherland, et al. 2010; Katayama et al., 2014). Birds play very important roles in ecosystems, for example, they control harmful insect and rodent populations, pollinate certain plants, contribute to organic substance cycles, and they promote environmental health by consuming carrion in nature (Oğurlu, 2000; Sekercioglu \& Riley, 2005; Öztürk \& Tabur, 2016). Birds are also rapidly affected by changes in environmental and climatic factors, and are, therefore, considered to be the most important indicator species for the sustainability of ecosystems (Burger \& Gochfeld, 2004).

Turkey is characterized by different habitat types as a result of its various climatic and topographic properties and this habitat diversity has resulted in the unique occurrence and richness of species (Grumbin, 1994). Bird diversity is known to approximately represent the total diversity of the ecosystem (Reif et al., 2016). The successful protection and management of the diverse array of bird species in Turkey can only be achieved with an understanding of their relations with environmental, climatic, and topographic factors (Donald et al., 2002; Kosicki \& Chylarecki, 2012). The potential impacts of these factors and the consequent temporal changes that occur can be estimated by determining which of these factors are more influential (Grumbin, 1994).

Many different indexes and mathematical formulas are used to calculate the alpha, beta, and gamma diversity values as components of biological diversity (Özkan, 2016). The alpha diversity indexes are comprised of traditional alpha diversity indexes and character-based alpha diversity indexes (Jost, 2006; Özdemir et al., 2017). Traditional alpha diversity indexes constitute the indexes that are based on the proportional or numerical values of the abundance data and species richness measurements (Özkan, 2016).

In this study, bird species diversity was calculated using various indexes based on the species richness calculation, which is among the first specified alpha diversity indexes. These indexes were then compared with each other with the aim of determining which environmental factors may account for the observed differences.

\section{Materials and methods \\ Study Area}

The study area covered a total of 60840 ha and was located in the city of Isparta District of Sutculer Village of Çandır (latitude: $37^{\circ} 31^{\prime \prime} 22^{\prime}$ and $30^{\circ} 42^{\prime \prime} 35^{\prime} \mathrm{N}$, longitude: $37^{\circ} 16^{\prime \prime} 40^{\prime}$ and $30^{\circ} 56^{\prime \prime} 49^{\prime} \mathrm{E}$ ). Nikon Monarch $12 \times 42$ binocular, a D-SLR camera and $400 \mathrm{~mm}$ telelens, a GPS, and study registration cards were used to conduct bird observations within the study area. Observations were conducted regularly in a total of 43 sample sites, throughout each month in 2016. Observations were conducted during 3 hours after dawn and for 3 hours before dusk each day, i.e., the times in which birds are most active, to obtain the required data of each observed bird species.

The slope, aspect, elevation, topographic position index(tpi), landform classification (lpi), slope position (sloppos), solar illumination (si), ruggedness, radiation index (ri), and heat index (hi) base variables of the study area were used and all of these variables were constructed using the program ArcMap 10.2 (Mert \& Kıraç, 2017).

The areas of the sample sites were then overlaid with the base variables and the cellular values corresponding to these points were attained. Climatic data were downloaded as 19 bio-climate data from www.wordclim.org and these data were adjusted to the scale of the study area.

\section{Data Analysis}

In the statistical process, a factor analysis based on the Principal component analysis (PCA) was first applied to enable the selection of the representative variables among the bio-climatic variables. As a result of this process, one component was 
identified to account for $48.37 \%$ of the observed variance. This component was thus selected as the representative variable [biol (r: 0.788)].

Species richness (S) (Peet, 1974), Menhinick $\left(D_{M N}\right)$ (Whittaker, 1977), Margelef $\left(D_{M G}\right)$ (Margalef, 1968), Shannon entropy $(H)$ (Shannon, 1948), Brilluoin $(H B)$ (Pielou, 1975), Simpson's 1-dominance (1- $\lambda)$ (Simpson, 1949), Fisher's Alpha $(\alpha F)$ (Thomas \& Shattock, 1986), and BergerParker (1/d) (Berger \& Parker, 1970) indexes have been used to measure the traditional alpha diversity of bird species (Özkan, 2016). Principal components analysis (PCA) was used to determine the distances of the calculated diversity indexes on the ordination axes and Pearson correlation analysis was applied to clarify the relationship between the diversity values and environmental and climatic variables. In the present study, factor analysis, correlation analysis, and PCA were run via RStudio (RStudio Team, 2020). BIÇEB software was also used for diversity calculations (Özkan et al., 2020).

$$
\begin{aligned}
& S=\sum_{i=1}^{S} s_{i} \\
& H=\sum_{i=1}^{S} p_{i} \ln p_{i} \\
& 1-\lambda=1-\sum_{i=1}^{S} p_{i}^{2} \\
& H B=\frac{\ln N !-\sum \ln n_{i} !}{N} \\
& 1 / d=\frac{N}{n_{\max }} \\
& D_{M N}=S / \sqrt{N} \\
& D_{M G}=(S-1) / \ln N \\
& \alpha_{F}=\frac{N(1-x)}{x}
\end{aligned}
$$

\section{Results}

\begin{tabular}{|c|c|c|c|c|c|c|c|c|c|c|c|c|c|c|c|c|c|}
\hline 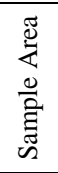 & 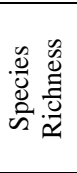 & 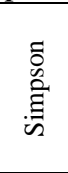 & 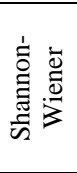 & $\frac{\Xi}{\Xi}$ & 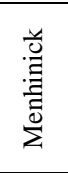 & 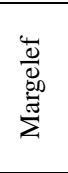 & 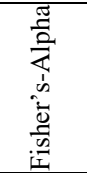 & 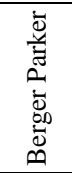 & 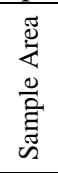 & 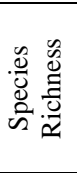 & 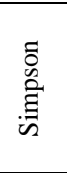 & 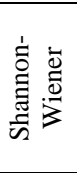 & 咅 & 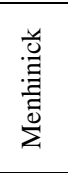 & 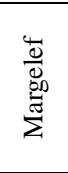 & 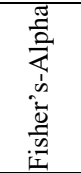 & 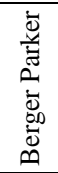 \\
\hline s1 & 25 & 0.91 & 2.77 & 2.38 & 2.87 & 5.54 & 12.99 & 5.84 & s23 & 10 & 0.85 & 2.04 & 1.82 & 1.27 & 2.18 & 3.37 & 4.13 \\
\hline s2 & 22 & 0.93 & 2.82 & 2.45 & 2.51 & 4.83 & 10.29 & 6.42 & s24 & 8 & 0.80 & 1.76 & 1.58 & 1.05 & 1.72 & 2.52 & 3.62 \\
\hline s5 & 16 & 0.88 & 2.39 & 2.11 & 1.82 & 3.45 & 6.14 & 4.81 & s27 & 11 & 0.85 & 2.03 & 1.83 & 1.30 & 2.34 & 3.62 & 4.50 \\
\hline s6 & 9 & 0.81 & 1.90 & 1.63 & 1.37 & 2.13 & 3.47 & 3.07 & s28 & 17 & 0.91 & 2.53 & 2.30 & 1.60 & 3.39 & 5.55 & 7.06 \\
\hline s7 & 7 & 0.76 & 1.62 & 1.41 & 1.09 & 1.62 & 2.43 & 2.93 & s29 & 18 & 0.91 & 2.58 & 2.32 & 1.77 & 3.66 & 6.28 & 6.50 \\
\hline s8 & 11 & 0.78 & 1.96 & 1.62 & 1.78 & 2.75 & 5.19 & 2.37 & s30 & 13 & 0.85 & 2.13 & 1.89 & 1.54 & 2.82 & 4.67 & 4.73 \\
\hline s13 & 18 & 0.91 & 2.57 & 2.34 & 1.66 & 3.56 & 5.92 & 7.37 & s35 & 15 & 0.84 & 2.21 & 1.87 & 2.08 & 3.54 & 7.06 & 3.25 \\
\hline s14 & 18 & 0.92 & 2.68 & 2.42 & 1.79 & 3.68 & 6.37 & 8.42 & s36 & 27 & 0.94 & 3.03 & 2.66 & 2.67 & 5.62 & 11.99 & 6.37 \\
\hline s15 & 12 & 0.87 & 2.22 & 1.94 & 1.56 & 2.70 & 4.55 & 4.21 & s37 & 22 & 0.92 & 2.70 & 2.43 & 2.06 & 4.43 & 8.11 & 7.12 \\
\hline s16 & 9 & 0.86 & 2.09 & 1.78 & 1.46 & 2.20 & 3.73 & 4.75 & s38 & 16 & 0.85 & 2.31 & 1.89 & 2.50 & 4.04 & 9.65 & 3.42 \\
\hline s17 & 24 & 0.94 & 2.97 & 2.58 & 2.67 & 5.23 & 11.52 & 9.00 & s39 & 18 & 0.90 & 2.51 & 2.25 & 1.85 & 3.73 & 6.58 & 5.94 \\
\hline s18 & 22 & 0.92 & 2.78 & 2.39 & 2.61 & 4.93 & 10.92 & 6.46 & $s 40$ & 16 & 0.90 & 2.41 & 2.18 & 1.58 & 3.24 & 5.33 & 7.28 \\
\hline s19 & 16 & 0.92 & 2.59 & 2.26 & 1.97 & 3.58 & 6.72 & 8.25 & s41 & 17 & 0.92 & 2.62 & 2.38 & 1.64 & 3.42 & 5.70 & 7.65 \\
\hline $\mathbf{s 2 0}$ & 11 & 0.85 & 2.11 & 1.83 & 1.51 & 2.52 & 4.22 & 4.08 & $\mathrm{~s} 42$ & 18 & 0.91 & 2.58 & 2.32 & 1.83 & 3.72 & 6.51 & 7.46 \\
\hline s21 & 14 & 0.89 & 2.38 & 2.09 & 1.72 & 3.10 & 5.44 & 4.71 & s43 & 14 & 0.88 & 2.31 & 2.05 & 1.66 & 3.05 & 5.22 & 6.46 \\
\hline
\end{tabular}

The species richness, Simpson, Brilluoin, Shannon-Wiener, Menhinick's, Margalef, Fisher's Alpha, and Berger-Parker index values of the 43 sample sites, calculated based on the diversity indexes, are shown in Table 1.

Table 1. Alpha diversity index values calculated for sample areas

The PCA, conducted to compare the alpha diversity indexes, produced 8 axes.
The PC1 and PC2 were found to have variances higher than $1 \%$ and ratios of 
participation to the variance higher than $10 \%$ (Table 2).

Table 2. Results of the PCA

\begin{tabular}{cccc}
\hline Axes & Eigenvalue & $\begin{array}{c}\text { Variance } \\
(\%)\end{array}$ & $\begin{array}{c}\text { Cumulative } \\
\text { Variance }(\%)\end{array}$ \\
\hline Axis1 & 6.666 & 83.33 & 83.336 \\
Axis2 & 1.131 & 14.19 & 97.475
\end{tabular}

Considering the relations among diversity values and the axes grouping them, Axis 1 was shown to be highly positively correlated with all diversity indexes and Axis 2 was shown to be partly negatively correlated with only Menhinick's index (Table 3).
Table 3.Pearson correlation analysis results applied between diversity values and axes

\begin{tabular}{lcc}
\hline Diversity Values / Axes & PC 1 & PC 2 \\
\hline Species Richness & 0.977 & -0.084 \\
Simpson 1-D & 0.886 & 0.396 \\
Shannon & 0.980 & 0.159 \\
Brillouin & 0.950 & 0.293 \\
Menhinick & 0.859 & $\mathbf{- 0 . 4 5 1}$ \\
Margalef & 0.962 & -0.229 \\
Fisher's alpha & 0.896 & -0.384 \\
Berger-Parker & 0.729 & $\mathbf{0 . 6 3 6}$ \\
\hline
\end{tabular}

All diversity values were then visualized on Axis 1 - Axis 2 axes to clarify the distribution of diversity indexes on the axes (Figure 1).

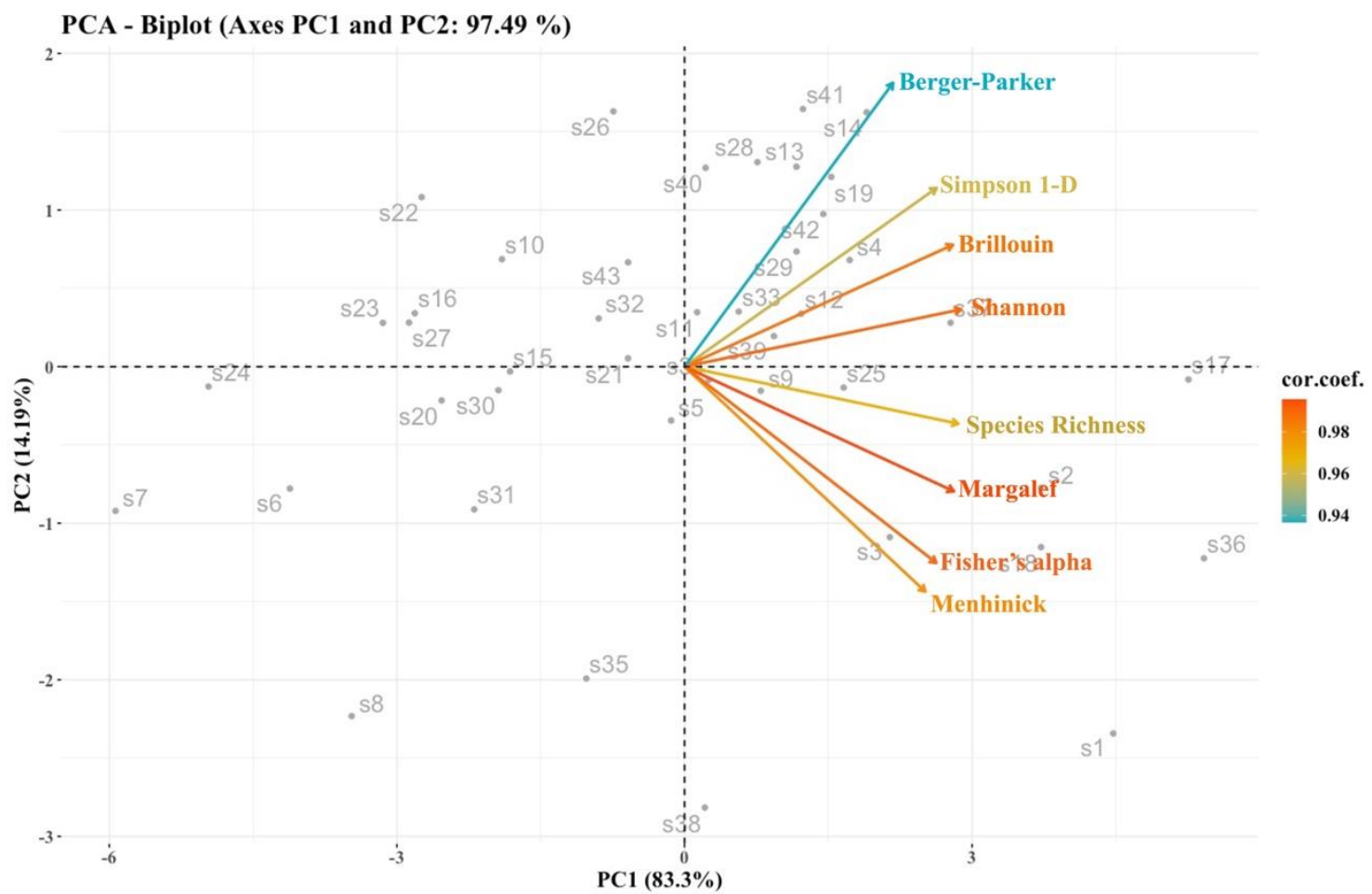

Figure 1. PCA results of the alpha diversity indexes

The PCA analysis revealed that species richness measurement and heterogenic indexes occurred in different groups depending on their axes.

The results of the Pearson's correlation analysis, which was conducted to assess the relationships between the alpha diversity indexes and variables and, thus, determine the factors that affected the diversity of the bird species, are shown in Table 4. 
Table 4. Pearson Correlation results applied between alpha diversity indexes and environmental variables

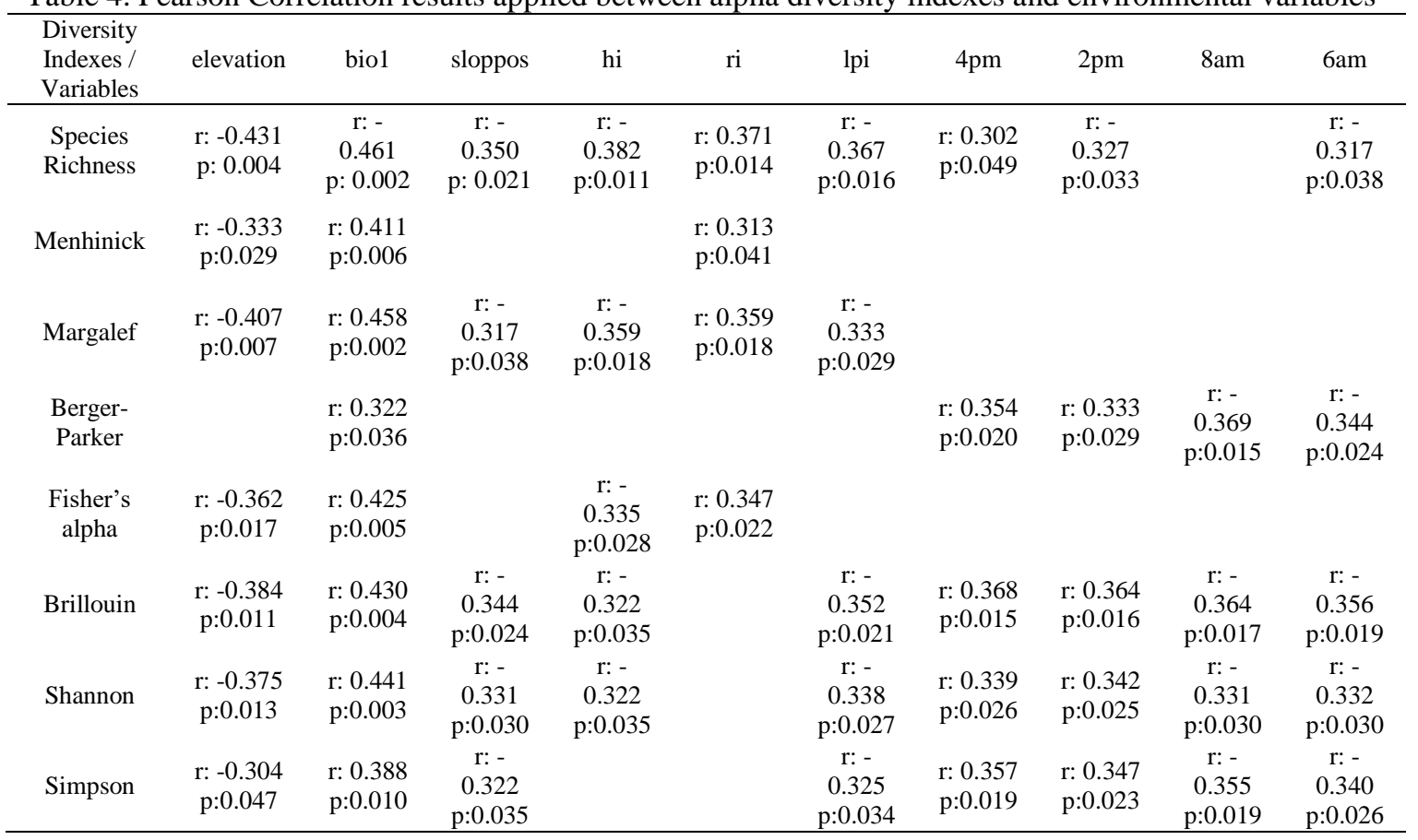

Species richness was found to be negatively correlated with altitude, annual average temperature, slope position, heat index, landform classification, and solar illumination ( 2 p.m. and 6 a.m.), and was found to be positively correlated with the radiation index and solar illumination (4 p.m.). Menhinick's index was shown to be negatively correlated with altitude and positively correlated with the annual average temperature and radiation index. Consistent with the results of the Menhinick's index, the Margelef index was also found to be negatively correlated with the heat index and slope position. Fisher's Alpha index showed similar results to these two indexes. Based on the abundance data, these indexes were generally positively correlated with annual average temperature and solar illumination (2 p.m., 4 p.m.) and negatively correlated with solar illumination (8 a.m., 6 a.m.). The Brilluoin, Shannon Wiener, and Simpson's indexes were shown to generally be negatively correlated with altitude, heat index, slope position, and landform classification. Only the Simpson's index was not shown to have any correlation with the heat index.

\section{Discussion and Conclusion}

According to PCA results of the alpha diversity indexes, the species richness measurements and heterogenic indexes formed different groups. These differences may be attributed the different base acceptances used in the different formulas. Among the heterogeneity indexes, only the Fisher's Alpha index is used to conduct species richness measurements. In previous studies, this index has been shown to give similar results to the species richness measurements (Shockat et el., 2001; Negiz \& Özkan, 2019).

The results of the study indicated that the bird species diversity was lower when the landform was classified as the canyon type $(32 \%)$ and when the slope position was classified as "ridge" (42\%). There is a known direct relation between the landform classifications and physiographic diversity (Theobald et al., 2015), and the results of the present study also indicated these factors to be important determinants of bird diversity.

All alpha diversity values were shown to be negatively correlated with altitude. Areas with higher variations in habitats and vegetation types have been shown to occur in the lower altitudes (Özkan, 2007), and both the number of species and their frequency 
have been shown to decrease with an increase in altitude. The results of the present study revealed a negative correlation between the diversity indexes and the heat index, whereby the decrease in the diversity of the bird species is dependent on the changes in climatic factors, such as temperature and air motions (Robbins, 1981; Thomas \& Lennon, 1999; Hitch \& Leberg, 2007). On the other hand, the annual average temperature has been shown to be a factor that determines the in-year activities and migrations of birds (Peñuelas et al., 2002). The present study revealed the factors that were negatively correlated with the species richness due to the fact that temperature especially affects the area preferences of the birds throughout different time periods. However, the indexes that considered the number of individuals, as well as the number of species, were shown to be positively correlated with the annual average temperature. Temperature was not only shown to directly and positively affect the number of individuals, but also the observance frequency of the species. Observance frequency was, therefore, used as an important parameter in the calculation of diversity in this study.

The bird diversities of the different study sites were generally shown to be negatively correlated with the slope position and heat index, as well as the landform classification. It is known that animal species do not generally prefer areas that are routinized and that have a weak distribution of habitat factors, such as food and water sources (Süel, 2014; Li et al., 2017). A possible reason for the negative correlation between the slope position and landform classification and the variability values may be attributed to the fact that the majority of the study area was routinized. Again, temperature may offer a possible explanation for these findings, due to it being an important factor that affects the mobility of animals (Van Rensburg et al., 2004).

It is important to conduct bird observations during the early hours of the morning and in the evenings (Shiu \& Lee, 2003). A comparison of bird diversity and solar illumination hours revealed a positive correlation with the solar illumination at 4 p.m., which is consistent with the data in published literature. Species richness was shown to be negatively correlated with afternoon solar illumination, due to most of the species showing reduced activities at 2 p.m. A negative correlation was observed between the diversity values and morning solar illumination (6 a.m. and 8 a.m.) which are convenient in terms of observation hour. The reason for this negative correlation may be explained by the fact that the morning sun reaches the area later because the study area is generally located in a canyon, therefore, the total solar illumination at these times is low, especially when compared to the daily solar illumination ratio.

In the present study, the calculation of bird diversity using different formulas revealed that the use of more than one diversity calculation method can conveniently be used to determine the factors that influence the diversity values in an area; because every diversity index works with different mathematical formulas and unique acceptances. The attained values from such calculations can differ. These differences can greatly and significantly influence the determination and interpretation of the factors that affect diversity. Various diversity indexes should, therefore, be collectively assessed in future studies to ensure higher accuracy of interpretations of influential factors and other data.

\section{Acknowledgements}

This paper has been presented at VIII. International Symposium on Ecology and Environmental Problems (ISEEP- 2017) and published in ISEEP-2017 Abstracts Book with the title "Determination Of Factors Affecting Bird Diversity; Çandır District Example".

\section{Ethics Committee Approval} N/A

\section{Peer-review}

Externally peer-reviewed.

\section{Author Contributions}

Conceptualization: H.S.; Investigation: H.S.; Material and Methodology: H.S., S.Ö.; Supervision: H.S., E.T.E.; Visualization: 
S.Ö.; Writing-Original Draft: H.S., D.A.; Writing-review \& Editing: D.A., S.Ö.; Other: All authors have read and agreed to the published version of manuscript.

\section{Conflict of Interest}

The authors have no conflicts of interest to declare.

\section{Funding}

The authors declared that this study has received no financial support.

\section{References}

Berger, W. H. \& Parker, F. L. (1970). Diversity of planktonic foraminifera in deep-sea sediments. Science, 168(3937), 1345-1347.

Burger, J. \& Gochfeld, M. (2004). Marine birds as sentinels of environmental pollution. EcoHealth, 1(3), 263-274.

Donald, P. F., Pisano, G., Rayment, M. D. \& Pain, D. J. (2002). The common agricultural policy EU enlargement and the conservation of Europe's farmland birds. Agriculture Ecosystems and Environments, 89, 167-182.

Grumbin, R. E. (1994). What is ecosystem management?. Conservation Biology, 8 (1), 27-38.

doi:10.1046/j.15231739.1994.08010027.

Hitch, A. T. \& Leberg, P. L. (2007). Breeding distributions of North American bird species moving north as a result of climate change. Conservation Biology, 21(2), 534-539.

Jost, L. (2006). Entropy and diversity. Oikos, 113(2), 363-375.

Katayama, N., Amano, T., Naoe, S., Yamakita, T., Komatsu, I., Takagawa, S. I., Sato, N., Ueta, M. \& Miyashita, T. (2014) Landscape heterogeneity-biodiversity relationship: effect of range size. Plos One, 9(3), e93359.

Kosicki, J. Z. \& Chylarecki, P. (2012). Effect of climate, topography and habitat on speciesrichness of breeding birds in Poland. Basic and applied ecology, 13(5), 475-483.

Li, Y., Brose, U., Meyer, K. \& Rall, B. C. (2017). How patch size and refuge availability change interaction strength and population dynamics: a combined individual-and population-based modeling experiment. PeerJ, 5, e2993.

Margalef, R. (1968). Perspectives in Ecological Theory: IL, 111. Chicago: University of Chicago press.

Mert, A. \& Kıraç, A. (2017). Habitat suitability mapping of Anatololacerta danfordi (Günter, 1876) in Isparta-Sütçüler District. Bilge International Journal of Science and
Technology Research, 1(1), 16-22, ISSN, 2587-0742.

Negiz, M. G. \& Özkan, K. (2019). Reproducing a component diversity index for regional biodiversity assessments. Fresenius Environmental Bulletin, 28(12 A), 9746-9752.

Oğurlu, İ. (2000). Biyolojik Mücadele: S.D. Ü. Yayın no:8, O.F. Yayın no:1. Isparta: Süleyman Demirel Üniversitesi Orman Fakültesi Yayınları.

Özdemir, S., Negiz, M. G., Turhan, U. U., Şenol, A. \& Arslan, M. (2017). Indicator plant species of alpha diversity in Kuyucak Mountain district. Turkish Journal of Forestry, 18(2), 102-109.

Özkan, K. (2007). Ecological properties of Yazili Canyon nature park. Republic of Turkey Ministry of Environment and Forestry, General Directorate of Nature Conservation and National Parks, Technical Report of GEF Project, 104.

Özkan, K. (2016). Biyolojik Çeşitlilik Bileşenleri $(\alpha, \beta, \gamma)$ Nasıl Ölçülür? Süleyman Demirel Üniversitesi, Orman Fakültesi Yayın No: 98, ISBN: 976-9944-452-89-2, Isparta, 142.

Özkan, K., Küçüksille, E. U., Mert, A., Gülsoy, S., Süel, H. \& Başar, M. (2020). Biyolojik Çeşitlilik Bileşenleri (BİÇEB) hesaplama yazılımı. Turkish Journal of Forestry, 21, 344-348.

Öztürk, Y. \& Tabur, M. A. (2016). Nesting Habitat preferences and reproductive performance of griffon vultures gyps fulvus (Hablizl, 1783) in Afyonkarahisar, Antalya, and Isparta (Turkey). Fresenius Environmental Bulletin, 25(9), 3303-3310.

Peet, R.K. (1974). The measurement of species diversity. Ann. Rev. Ecol. System., 5, 285-307.

Peñuelas, J., Filella, I. \& Comas, P. (2002). Changed plant and animal life cycles from 1952 to 2000 in the Mediterranean region. Global Change Biology, 8(6), 531-544.

Pielou, E.C. (1975). Ecological Diversity, New York, Wiley InterScience.

Reif, J., Hanzelka, J., Kadlec,T., Štrobl, M. \& Hejda, M. (2016). Conservation implications of cascading effects among groups of organisms: the alien tree Robinia pseudacacia in the Czech Republic as a case study. Biological Conservation, 198, 50-59.

Robbins, C.S. (1981). Bird activity levels related to weather. Studies in avian biology, 6, 301310.

RStudio Team (2020). RStudio: Integrated Development for R. RStudio, PBC, Boston, MA URL http://www.rstudio.com/.

Sekercioglu, Ç. H. \& Riley, A. (2005). A brief survey of the birds in Kumbira Forest. Gabela, 
Angola. Ostrich-Journal of African Ornithology, 76(3-4), 111-117.

Shannon, C.E. (1948). A Mathematical Theory of Communication, The Bell System Technical Journal, 27, 379-423. doi: 10.1002/j.15387305.1948.tb01338.x.

Shiu, H. J. \& Lee, P. F. (2003). Assessing avian point-count duration and sample size using species accumulation functions. Zoological Studies, 42(2), 357-367.

Shochat, E., Abramsky, Z. \& Pinshow, B. (2001). Breeding bird species diversity in the Negev: effects of scrub fragmentation by planted forests. Journal of Applied Ecology, 38(5), 1135-1147.

Simpson, E.H. (1949). Measurement of diversity, Nature, 163, 688. doi:10.1038/163688a0.

Sutherland, W. J., Albon, S. D., Allison, H., Armstrong-Brown, S., Bailey, M.J., Brereton, T. \& Hill, D. (2010). The identification of priority policy options for UK nature conservation. Journal of Applied Ecology, 47(5), 955-965.

Süel, H. (2014). Mapping habitat suitability of game animals in Sütçüler district, Isparta. Doctoral Thesis, Suleyman Demirel University, Isparta, 151. (in Turkish)

Tews, J. U., Grimm, B. V., Tielbo“rger, K., Wichmann, M. C., Schwager, M. \& Jeltsch, F. (2004) Animal species diversity driven by habitat heterogeneity/diversity: the importance of keystone structures. J Biogeogr, 31, 79-92.

Theobald, D. M., Harrison, Atlas, D., Monahan, W. B. \& Albano, C.M. (2015). Ecologicallyrelevant maps of landforms and physiographic diversity for climate adaptation planning. Plos One, 10(12), e0143619.

Thomas, C. D. \& Lennon, J. J. (1999). Birds extend their ranges northwards. Nature, 399(6733), 213-213.

Thomas, M. R. \& Shattock, R.C. (1986). Filamentous fungal associations in the phylloplane of Lolium perenne, Transactions of the British Mycological Society, 87(2), 255286. doi:10.1016/S0007-1536(86)80029-8.

Van Rensburg, B. J., Erasmus, B. F. N., Van Jaarsveld, A. S., Gaston, K. J. \& Chown, S. L. (2004). Conservation during times of change: correlations between birds, climate and people in South Africa. South African Journal of Science, 100(5), 266-272.

Walker, B. (1995). Conserving biological diversity through ecosystem resilience. Conservation Biology, 9(4), 747-752.

Whittaker, R. H. (1977). Evolution of species diversity in land communities. In Evolutionary Biology, (eds M.K. Hecht, W.C.
Steree and B.Wallace), Plenum, New York, 10, 1-67. 